\title{
SELECTED WAYS OF ACQUIRING SECURITIES IN THE CONDITIONS OF THE SLOVAK REPUBLIC
}

\author{
Tomáš Peráček , Boris Mucha², Patrícia Brestovanská , Jana Kajanová2 \\ ${ }^{1}$ Department of Information Systems, Faculty of Management, Comenius University in Bratislava, Šafárikovo \\ námestie 6, 81499 Bratislava, Slovak Republic \\ ${ }^{2}$ Department of Economics and Finance, Faculty of Management, Comenius University in Bratislava, Šafárikovo \\ námestie 6, 81499 Bratislava, Slovak Republic
}

To cite this article: PERÁČEK TOMÁŠ, MUCHA BORIS, BRESTOVANSKÁ PATRÍCIA, KAJANOVÁ JANA. 2018. Selected Ways of Acquiring Securities in the Conditions of the Slovak Republic. Acta Universitatis Agriculturae et Silviculturae Mendelianae Brunensis, 66(6): 1589-1599.

To link to this article: https://doi.org/10.11118/actaun201866061589

\begin{abstract}
One of the basic tools of the capital market are securities. Under the currently valid and effective legislation, ownership of securities can be acquired through three types of scrambling contracts. It is a contract for the purchase of securities, a contract for the donation of securities and a contract for the loan of a security. These contract types are primarily regulated in the Securities Act as the "lex specialis" of securities law, with subsequent reference to the legal regulation contained in the Civil Code and the Commercial Code. The authors are focused on a donation of securities lending of securities, which are used in practice only a little, or even at all. For this reason, no attention is paid to them either by legal theorists. The authors, through scientific and doctrinal interpretation, examine the selected provisions of the Securities Act, the Civil Code and the Commercial Code relating to the issues of these agreements. Through professional literature and court decisions, they are looking for answers to practical application problems. Last but not least, they compare legal regulations in Slovakia and the Czech Republic and point to the differences. The study of the selected issues related to the acquisition of securities in the conditions of the Slovak Republic represents the main objective of this contribution, which affects also the area of economics or financial management. Priority, however, is in the area of financial law with significant transitions to civil and commercial law.
\end{abstract}

Keywords: agreements, donation, loan, securities

\section{INTRODUCTION}

The capital market is understood as a system of institutions and instruments providing movement of medium and long-term capital between economic entities through different forms of securities by economic theory. Unlike the money market, the range of subjects on the capital market is wider and the market organization is more diverse (Revenda et al., 2014). Its integral part is stock exchange as special business contracts. Their key feature is that they are closing on a stock market that differs from other markets by their high formal organization. The transfer of capital in the form of securities takes place on the basis of concluded securities agreements (Lewin, 1999). In the conditions of the Slovak Republic this legal institute is regulated by Act no. 566/2001 Coll. on securities and investment services, as amended (hereinafter "the Securities Act"), which replaced the previous Act no. 600/1992 Coll. on Securities that no longer meets the needs of 
the capital market and responded to the expected increase in possible legal relationships regarding securities and, in particular, the expected increase in trading with this commodity.

Securities Transaction Agreements are important financial instruments of the financial market for the exchange of the securities owner. (Dědič and Pauly, 1994). The securities donation agreement and the securities lending agreement are very strictly regulated by the Securities Act, while the law refers to the modification of the contractual types in the Civil Code, respectively in the Commercial Code. Eliáš et al. (1999) states that the provisions of Paragraphs 30 to $53 \mathrm{f}$ of the Securities Act governing the issues of securities contracts constitute lex specialis in relation to both Codes.

In recent years, the number of securities donation and securities lending agreements have been significantly reduced. This is, in our view, the consequence that even legal theorists dealing with the issues of securities law and commercial law avoid this topic. They give it little space in their research, despite their importance in business practice. This is why we have chosen, through scientific and doctrinal interpretation, to override selected paragraphs of the Securities Act, the Civil Code and the Commercial Code relating to the issues of the agreements chosen by us.

The structure of the paper corresponds to our intention, which is divided into two main chapters in addition to the introduction and the combined discussion. Each of these chapters comprehensively examines one contractual type. The special space in the last chapter deals with their comparison with the Czech legislation. At the end of the paper, we confirm or reject the hypothesis that the agreement for securities donation and the agreement for securities lending are separate contractual types.

\section{The aim of the paper and the methodology}

The main purpose of this paper is to identify the securities donation and securities lending agreement and to review their legal regulations in the conditions of the Slovak Republic. Besides the main objective, we also chose several sub-objectives, namely:

- Comparison of the Slovak and Czech legislation on securities donation and lending,

- Confirm or reject the hypothesis that the securities donation and securities lending agreement are separate contractual types in Slovak commercial law.

We want to achieve the chosen objectives in particular through the use of legislation, professional and scientific literature as well as Czech and Slovak jurisprudence.

Given the nature of the paper, we apply scientific methods that represent immanent methods that lead to highly qualified human activities aimed at obtaining scientific knowledge, to penetrate from phenomenon to the substance. The result of this activity is new knowledge that is organized into a certain system (Knapp and Gerloch, 1983). For the discovery of law, we consider it appropriate to use the logic method that can be used in all sciences, and also the abstraction method, without the use of this method the work could, due to its wide range act unintentionally or chaotically. Required method is also logical analysis, which requires that the system that is analyzed in order, with the ultimate goal to uncover this pattern, it is a necessary method for successful processing of the given issue (Filkorn, 1956).

We also used the analytical method to analyze legal status and legal regulations from the scientific methods of knowledge. Using the comparative method, we tried to make different views on the legal regulations and the interpretation of the individual institutes, as well as on the comparison of the Slovak and Czech legislation. Based on the scientific knowledge of valid and effective law and legal science, we have also used doctrinal and scientific interpretation in some parts of the paper.

In Slovakia, a number of authors or theoreticians are in the field of law, such as I. Fekete, M. Patakyová, M. Mamojka, J. Králik, and especially in university textbooks, professional and scientific articles are found in the field of law securities, commercial law and civil law. Securities agreements were also analyzed by theoreticians in the Czech Republic, among whom we can mention the renowned authors J. Dědič, K. Eliáš, J. Kotásek, V. Pihera, J. Vítek, K. Marek, J. Bejček, J. Pokorná and others. A special place as a source of knowledge belongs to the decision-making activities of Slovak and Czech courts.

\section{Agreement on the donation of securities}

The donation agreement (lat. "donatio"), together with a contract of sale, a contract of exchange and a loan agreement, is the best-known type of free-of-charge contract. Free-of-charge as the basic feature manifests that the donor does not receive any property in exchange for the donation. From the point of view of legal theory, it is the application of the principle of liberalism, which means that donation must not be a fulfilment of a legal obligation that would result from a lawyer or an agreement. Signs of the donation agreement are complimentary and voluntary (Dukalová Jakubekova et al., 2013). It is not complimentary if the donation is linked to specific obligations, for example, in the donor's order against the gifted person to behave in such a way that ultimately brings the property benefits to the donor. We cannot, for example, understand voluntarity as a fulfilment of a certain statutory obligation.

The Securities Act does not specify the characteristics of the securities donation agreement, it only submits it to the Civil Code and in the Code gives it only one sentence. This is a statute of Paragraph 30 section 4 of the Securities Act, according to which the agreement for the donation of securities is governed by the statute of the Civil Code on the Donation agreement, 
unless the Securities Act provides otherwise (Výboch, 2009).

The donation of a security can be defined as a contractually-legal relationship based on a signed agreement, which the donor passes free of charge or promises to the donor and accepts the donation or promise. Donation is a bilaterally-legal act, it is not only the expression of the will of the donor, but must be expressed positively, even if only tacitly (silently), and so it is excluded that the donation donated will be against the will. This is supported by the law that if a donation is sent to the recipient by mail as a parcel, the receipt of the donation does not come from the actual taking over of the consignment but only after the recipient has decided to accept the donation after unpacking. This must be counted with a certain amount of time, in which the donated person may become acquainted with what was given to him. This opinion is based on the Judgment of the Supreme Court of the Czech Republic no. $4 \mathrm{Cz} 17 / 91$ on a Complaint about breaking the law by the Regional Court in Ústí nad Labem, which confirmed the decision of the State Notary in the case of Heritage (Czechoslovak court decision no. 26/1992).

The agreement for the donation of a security is therefore a unilateral agreement on the basis of which one party - the donor surrenders at the expense of his property to the other party, endowed free of charge and without any legal obligation to property, with intent to reproduce his property, and the other party receives such payment as free of charge. The donation is therefore followed by the gratuitous reproduction of the donated property at the expense of the donor's property, and that is the basis for its function. However, if the donation agreement was concluded in order to satisfy the claim of donated against the donor, according to the judgment of the Supreme Court of the Slovak Republic (2006) in the case of such an action for the invalidity of a donation agreement for an invalid legal act. Using the „analogia legis“ legal institute, it is possible to determine the essential requirements of the securities donation agreement:

1. designation of the parties, j. who is the donor and who is a gifted person,

2. determination of the donor's obligation to leave or promise the security,

3. determining the obligation of the recipient to take over promised securities.

Unlike general legislation, the Securities Depository Agreement must be in writing in accordance with the Statute 30, paragraph 4, second sentence of the Securities Act. The absence of a written form as well as some of the mandatory terms of the agreement would mean that the agreement as a legal act would be affected by an absolute nullity. "Absolute invalidity occurs directly by law (ex lege) and acts against everyone, which means that everyone can call for it. Absolute invalidity is controlled by the court. In particular, it must be pointed out that the defect of absolute nullity of a legal act cannot be remedied either by subsequent approval or can be reconsidered (remedied) by an additional failure to act on the ground of invalidity" (Lazar, et al., 2018).

The legislation of the donation agreement also takes into account some principles of inheritance law, prohibiting donation to be connected to the moment of the death of the donor (donatio mortis causa), and therefore Paragraph 628, Section 3 of the Civil Code provides that the donation agreement, which is to be fulfilled after the donor's death, is invalid. This is also an absolute nullity, which in practice means that even if such donation exists, it would have no legal effect and the donated security would be the subject of the inheritance of the donor. "This is a ban enshrined in our legal order since 1950 in the Civil Code, which has removed the legal dualism of private law in Czechoslovakia. The reason for its introduction was, and at present is, the limitation of the trustee in dealing with his property besides the existing heir titles the inheritance of the will by the law" (Fekete and Feketeová, 2006).

It follows from the above that the general rules on the donation of securities include two factors:

1. the conclusion of a written agreement on the donation of securities, which represents the legal title of the gift ("titulus"),

2. handing over the gift to the recipient ("modus").

In this connection, however, we must distinguish between the contractually-legal and the legally-binding effects of the agreement. The legally-binding effects of such an agreement occur at the time of its conclusion, provided that all legal requirements are met and that the right of the parties to dispose of their property is not limited, for example, due to deprivation of legal capacity by a participant. Generally speaking, if the agreement was concluded by a person who is limited by court to withdrawn the right to dispose of his property or it would have been the agreement that the donor made by mistake in accordance with Paragraph 49 of the Civil Code, that agreement would be totally invalid by law and would not have an effect on. The agreement where the non-owner of the security would appear on the donor's side would also be affected by the absolute nullity. However, it is questionable whether it is also possible to apply to a securities donation agreement by analogy od the Paragraph 19 Section 3 of the Securities Act, according to which unless the special law provides otherwise, the buyer becomes the owner of the security, even though the seller has no right to transfer that security, unless the buyer knew at the time of the transfer or had to know that the seller had no right to transfer the security. In our opinion, the application of such an analogy is essential.

However, the non-statutory effects of the securities donation agreement may vary. It results from the Paragraph 133, Section 1 of the Civil Code that the substantive effects of the donation agreement, the object of which is the movable thing and the securities belonging to this category, arise when the donation is transferred to the property by the tradition. This is especially true of so-called 
scriptures known as promissory notes. Especially, for securities called "of the series" it is necessary to carry out the "indosament". Bearer securities are transferred by tradition. In the case of securities donation, the law distinguishes between the documentary and the booked (electronic) form of the security. In the case of the donation of a documentary security, the material effects of the contract become effective by handing the security to the gifted person. However, in the case of dematerialized securities, it is necessary to apply the Paragraph 22, Section 1 of the Securities Act that in a congenial manner stipulates that the donor's obligation to transfer to the dematerialized book-entry security is met by the registration of its transfer made by the central depository or a member of the central depository of the order for registration of the transfer of the book-entry security, if the transferred security corresponds to the agreement. The registration of the transfer of the book-entry security has constitutive effects and is defined as the execution of the registration in the statutory register of the owners of the dematerialized securities, on the account of the transferor's owner or the holder's account and in favour of the account of the owner of the acquirer or the holder's account. The debit notes and the accounts of the owners are the central depository or a member required to execute on the same day (Eliáš et al., 1999)

Usually, the process of registration of securities donation agreement lasts for several days and may also result in the death of the party of the contract during that period. As stated in the decision of the Supreme Court of the Slovak Republic, the death of the participant in the donation agreement (the donor) is not in itself a reason for the interruption of the proceedings; some rights and obligations of the bearer pass through death to others. Such rights and obligations also include the commitment of the parties to their manifestations of will to the formation of a contract to which a competent decision of the competent authority is still required, as required by Paragraph 47 of the Civil Code. "This commitment also applies to the heirs of the dead participant who join into his rights and obligations under a civil law relationship. They are therefore also parties to the registration procedure" (Mikita, 2003).

In particular, it is necessary to point out the handling of securities belonging to the estate of entirety of married couples. The donation of a security belonging to the estate of entirety between the spouses is not possible due to circumvention of the mandatory Statutes of $\S 143$ to $\S 144$ of the Civil Code governing the extent of the estate of entirety. Each spouse is entitled to own the whole subject; the rights of one of the spouses are limited by the same rights of the other spouse. Thus, if each of the spouses is entitled to own the whole thing, that is, to a security restricted by the same right of the other spouse, then one of the spouses cannot transfer this right to the other spouse, not even by a donation agreement (The Conciliatory opinion of the Supreme Court of the Czech Socialist Republic on the estate by the entirety, (Czechoslovak court decision no. 42/1972). What the legislature does not exclude, however, is the possibility of a donation of a security to third parties, to their own children. In that case, both spouses will appear on the donor side. The written form of the securities donation agreement removed the possible dispute how it would be necessary to interpret the donor's will to donate the security to his spouse, at marriage. This question is addressed by Judgement no. 42/1972, according to which the donation of a donor is the decisive intention of the donor in the case of donation of a spouse to another person in order to judge who is endowed in the sense of whether he wanted to give a case to one of the spouses or both. This intention may in most cases be judged by the circumstances in which the donation arises. It is not sufficient to assess the nature of the donated object, whether it serves only to the needs of one of the spouses or the whole family, but it must always be based on the intention of the donor. Since, the securities donation agreement must be written in writing, it should also include determining the relation of the estate of entirety of the spouses in the donated security. If such a data were not included, the spouses would acquire a security in their estate of entirety each in one half because the objects acquired by the donation are not part of the estate of entirety of the spouses.

The donor's fundamental duties include the obligation to transfer the subject of the contract - securities to the donee and they are entitled to claim their fulfilment. Donor cannot get rid of his commitment by giving the recipient a different subject of performance. The subject of the donation may also be taken over by the donor himself or by another person commissioned by the donor for this act. After taking the securities, however, they are obliged to hand them over immediately to the gifted person, and if they do not, they would commit the crime of fraud. In practice, the perpetrator took over the security from the donor in order to hand it to the donored person but did not transferred the donation but arbitrarily adopted it (Supreme Court of Czech Republic, 2003).

"The consequences of breaching the obligations of the donation agreement are the same as for the other contractual commitments. However, the donation agreement is not a synalagmatic commitment, and therefore only a gifted person can claim fulfilment, which is a donation. It is true that the right to claim is also fulfilled if the donor does not fulfil what he has promised" (Vojčík et al., 2010). For securities donations, the Statutes of Paragraphs 499 to Paragraph 510 of the Civil Code on Liability for Damage cannot be applied as it is a free transfer of ownership. Even so, the donor is obliged to alert the donee already when offering to give him the security for his defects, of which he knows, under the responsibility of the damage under 
$\S 420$ et seq. The Civil Code, which was caused by a donated security.

Since donation is a free legal action from the donor towards the recipient, the donor is therefore not responsible for any defects in the donation under the general Statutes of the Civil Code on Liability for Damages. However, in this context, it is the duty of the donor to draw the attention of the recipient to the defects of the securities he knows about. It can be defect like, for example, damaged paper, which lacks any part but also legally defect, the right of lien in favour of a third person to the donated share. However, the donor has such an obligation only in relation to the defects he or she knows. If such defects are silenced, the Civil Code grants to return the donated security. However, it must be a defect that had a security at the time of the conclusion of the contract. Also, the right of the recipient to return a security is subject to a limitation period of three years in the general limitation period in Paragraph 101 of the Civil Code, which begins on the day on which the defect can be ascertained under normal liability.

\section{Return of the donated security}

By concluding a contract for the donation of the security and the subsequent registration of this agreement in the case of the booked securities, by taking over a booked security, the donee becomes its owner and can be treated as the law allows, can handle it and take advantage of it.

The mandatory Statutes of Paragraph 630 of the Civil Code regulates a special way of terminating the donation agreement in such a way that it allows the donor to demand the return of the donation in the case that the donee behave to the donor or people close to him in such a way that he grossly violates good morals. The Austrian General Civil Code also contains the same legal institute in the Statutes of Paragraph 948 under the title "Unfairness". Judicial practice, however, is of the view that this Statute considers as legitimate only the behaviour of the donee, which was objectively manifested. The subjective feeling and judgment of the donor is not decisive (Supreme Court of Slovak Republic, 1997). This is the legitimate reason why the donor may demand the return of the donation. However, it is necessary that the degree of amoral behaviour of a gifted person can be classified as a gross violation of good manners, which according to court practice can in no way be only a subjective feeling of ingratitude, the sale of donated securities to a third person, not visiting of a donor during their jubilee, However, such a proceeding may only be granted by a donated person. Behaviour of members of the donated family to the donor is inapplicable by the Section 630 of the Civil Code. This Statute cannot be interpreted in a way, so that the consequences of the behaviour of other persons except for the donated person, even people close to him. It would not be fair to demand from a donated person to incur sanctions for the behaviour of others against a donor who is not responsible for it (Supreme Court of Slovak republic, 1999).

The formulation that the "donated person behaves" cannot be explained in such a way that the violation of good morals must still exist at the time of the call for the return of the donation. Donor can demand the return of the gift even if the disconcerting condition does not last, but the violation of good morals occurred in the past. The donor can only "demand the return of the donation" on the basis of a call for the donation return. Dedicating for the donation return is a unilateral legal act, which seeks the donee to return the donation to the donor. And this appeal as a legal act must satisfy all the requirements of the Statutes of Paragraph 37 of the Civil Code that the call fort the return must be done freely, seriously and comprehensibly. The formal side of the call is not set by law. It must, however, be clear that the donor's desire is for the donee to return the donated security. In general, however, it can be clearly recommended that this call for return must be made in a demonstrable way, in particular, in order to prove that the return request was set clearly and contained all the items that it should contain. In particular, the call itself contains a clear and unmistakable description of the facts which, in the donor's opinion, give him the right to demand the return of the donation (Supreme Court of Slovak republic, 2002).

As it results from the Czech judicial practice for the expression of the donor's will to the recipient, it is considered an action by which the prosecutor seeks to return the donation at the moment of delivery to the recipient (Supreme Court of Czech republic, 2001). In such a case, the claim for the return of the donation is replaced by the action itself as if it fulfils the prescribed requirements of substantive law. The claim for return of the donation must be contained in the part of the application, which contains a description of the decisive facts. "By delivering the equivalent copy of such an application to the recipient is then fulfilled by the substantive condition for the termination of the legal relationship from the donation agreement" (Fekete, 2015).

The law does not set any time for the donor to demand the return of the donation. However, he or she must apply to the court not later than three years from gross violation of good morals; otherwise the success of his claim in court could be avoided by the donee's objection. The donor has to return everything he has received from the donor, that is, he must return the donated securities. If they do not have it, they return the refund, expressed in money at the time of the cancellation of the contract.

\section{Securities Loan Agreement}

An agreement for a security loan as a special agreement type is enshrined in Statute 38, Paragraphs 1 to 3 of the Securities Act and, unlike the contract for the purchase of securities and the securities donation agreement, contains a legal definition (Králik and Jakubovič, 2004). 
Securities loan is based on the same principle as a loan of funds. The creditor will provide the debtor for a period of time with repository securities and, in return, for not being able to dispose of these securities during the lifetime of the loan, the debtor will undertake to pay the remittance. Remuneration is usually paid in money, but it is possible to negotiate another form of retaliation, e. g. The borrower may transfer to the lender a greater number of securities than he has borrowed.

As is clear from the legal definition of a securities loan agreement, this is, by its nature, free of charge and free of charge, only the possibility of agreement termination is expressed by the conditional third sentence of the introductory statement in Paragraph 38, Section 1 of the Securities Act "if agreed".

The Securities loan agreement represents the creditor's obligation to transfer ownership of a certain number of securities to the debtor, and the borrower undertakes to transfer the same number of collateralized securities to the lender after the agreed maturity period, together with the payment of the redemption if agreed. The law allows the parties instead of retaliation, expressed in money, to agree on the creditor's remuneration consisting in the return of a larger number of securities to be repaid than the amount lent to the borrower by the lender. However, it is particularly important to point out that it is inadmissible for the agreement to include the simultaneous negotiation of contractual interest and a contractual fine. Non-payment of contractual interest within the agreed period entitles the creditor to reclaim from the borrower also the interest on the delay (Supreme Court of Czech Republic, 2002). In addition, the validity of the securities loan agreement requires that the type of security must be determined, the number of securities transferred and their ISIN if assigned. It follows from the above that the essential parts of the securities lending agreement are:

l. designation of the parties, who is the creditor and who is the debtor,

2. the creditor's obligation to transfer to the borrower the right of ownership of a certain number of fungible securities precisely identified by type, number and ISIN if assigned,

3. the debtor's obligation to transfer to the lender, after the expiry of the agreed term, the same number of fungible securities, together with the payment of redemption if agreed.

The securities loan agreement must be written in writing as a result of a damage of absolute nullity. In view of the negative definition of the subject of the securities loan agreement with reference to the Statute of Paragraph 38, Section 1 of the Securities Act may not be the subject of a contract of unsubstitutable securities, such as deposit book or bill of exchange. This is also supported by the Statute of Paragraph 657 of the Civil Code on Species Determined by Type.
The loan agreement as a named (nominate) contract is governed by Paragraph 657 and Paragraph 658 of the Civil Code. Nevertheless, the Securities Act stipulates that commitment relationships arising from the repayment agreement about the security loan are governed by the Statutes of Paragraph 261 et seq. Commercial Code, its general Statutes on trade commitments. However, on the other hand, the Statutes of Paragraphs 488 to 587 of the Civil Code apply to commitment relations from a repayment securities loan agreement.

The securities loan agreement arises by the parties' agreement that the lender passes to the borrower the specified securities and the borrower returns the securities of the same type at the agreed time. The agreement may not include a due date, the day of return of the borrowed securities. The obligations of the parties include the transfer of the object of the loan to the debtor in order to acquire ownership of it, which implies that the object of the agreement should not be affected by a legal defect impeding the acquisition of the right of ownership. As with the donation of booked securities, the mandatory registration of the loan for the booked security is part of this process. In the case of a loan of a written security paper, it is necessary for the transfer of ownership to execute, in addition to the conclusion of the written contract and transfer of the security, to make endorsement of securities, which is relatively often confused only with the transfer of the security to the debtor (Baumach and Hefermehl, 1997).

Even in the case of a security loan, the estate of entirety in certain areas limits the freedom of contract. Loan of a security belonging to the estate of entirety between the spouses is not possible, as in this case each spouse has the right to the whole part of the security and the right of one of the spouses is limited by the same right of the other spouse. However, they may borrow such securities to third parties. However, if a security belonging to the spouse was renounced by only one of them without the consent of the other spouse; such an agreement would be affected by a relative invalidity.

The basic obligation of the borrower is to return the borrowed securities at a specified time, while the maturity is not a condition of the agreement's validity. If the maturity is not agreed upon in the agreement, the general provision of Paragraph 563 of the Civil Code applies in the case of a free-of-charge securities lending agreement, whereby the time of fulfilment is not settled, determined by law or specified in the decision, the debtor is obliged to repay the debts at the first day after the creditor asked him to do so. Another period of maturity of a loan is applicable to an agreement of pledge governed by the statutes of the Commercial Code, whereby the time of performance is not specified in the agreement, the creditor is entitled to demand fulfilment of the obligation immediately after the conclusion of the agreement, and the debtor is obliged to fulfil the obligation without undue delay after 
the creditor requested it (Bullow, 1991). However, it should be emphasized that the borrower is entitled to return the borrowed securities earlier, before maturity.

The parties may agree that the due date will be determined by the debtor. However, this solution is considerably disadvantageous to the creditor, because if the debtor will not want or cannot repay his debt, the creditor will not have anything else but only with the meaning of Paragraph 564 of the Civil Code or with the Paragraph 341 of the Commercial Code to apply to the court to determine the maturity, on the nature and place of performance, as well as the reason why the determination of the performance time was left to the debtor.

When dealing with the issue of the proper return of a lent security, the borrower is obliged to return the borrowed securities at once. However, if the subject of the loan is divisible, when it comes to two securities, it is possible to repay the loan even in parts (Brox, 1983).

In the case of securities loan contract which, as has already been stated, is of a gratuitous nature, it is necessary to draw attention to the ability of the parties to agree on interest as a reward for the lender, as well as default interest which would constitute a sanction against the debtor for late payment of the loan. Even there, however, the contractual freedom of the parties is limited. Saved interest, e.g. at the rate of 66 per cent per year, has been regarded by the judicial practice as wicked for more than ten years, agreed as violation of good morals or the principles of honest business relations, and therefore cannot use legal protection. In practice, this means that the creditor cannot even successfully sue the court to pay such interest, respectively non-monetary rewards (Supreme Court of Czech Republic, 2002).

The agreement for a loan of a repossessible security most often terminates by fulfilling its purpose, it means by returning the same kind of the security. In addition to fulfilment, the agreement may terminate by the creditor's agreement with the debtor on the termination of the agreement, or the replacement of the loan agreement with another bond-legal relationship, by concluding a legally uncontracted agreement for the exchange of securities within the meaning of Paragraph 611 of the Civil Code. In addition, the agreement may be terminated in certain cases on the basis of a legal event such as the death of the creditor, when the person of the debtor and the creditor may come into contact. A particular way of terminating an agreement is, for example, impossibility to execute or forgiveness of debt by the creditor to the debtor.

\section{Statistical data}

We believe that the results of our investigation should also be based on the statistical data provided to us by the Central Securities Depository upon our personal request. From the above Tab.I it is possible to assess the current trend of registration of selected agreements.

\section{Donation and loan of the securities in the conditions of the Czech Republic and their comparison with the Slovak legal regulation}

In the Czech Republic, the legislation on transfers of securities, unlike the Slovak legislation, is different. The Czech legal order respected the general tradition of securities legislation subject to special rules. By the end of 2013, the legal nature and requirements for securities related to their issuance, forms, changes in the shape or types of securities contracts regulated by the Securities Act (Kotásek, 2017). After the recodification of private law, this area with minor modifications was included in the Civil Code (Act No. 89/2012 Coll., Civil Code).

By repealing the Act no. 591/1992 Coll. on Securities, it was liquidates as a separate agreement type as well as the agreement for the donation of a security. For this reason, the donation of the security is currently subject to the provisions of § 2056 to 2078 of the Civil Code on the Donation Agreement. Although both in Slovakia and in the Czech Republic the donation agreement is defined in the same way, the regulations show some differences. From the point of view of the form of this agreement, the Czech legislature, unlike the Slovak one, does not require a written form under any circumstances. It insists on it only in two cases. The first is the donation of securities listed

I: The Central Securities Depository (2018)

\begin{tabular}{lccc}
\hline Year & $\begin{array}{c}\text { Agreement for the purchase of } \\
\text { a security }\end{array}$ & $\begin{array}{c}\text { Agreement for the donation of } \\
\text { a security }\end{array}$ & Agreement for securities loan \\
\hline $\mathbf{2 0 1 0}$ & 18.198 & 86.248 & 4 \\
$\mathbf{2 0 1 1}$ & 20.169 & 91.341 & 0 \\
$\mathbf{2 0 1 2}$ & 33.951 & 189.413 & 0 \\
\hline $\mathbf{2 0 1 3}$ & 28.885 & 106.221 & 4 \\
$\mathbf{2 0 1 4}$ & 22.295 & 95.258 & 0 \\
$\mathbf{2 0 1 5}$ & 16.397 & 38.054 & 0 \\
$\mathbf{2 0 1 6}$ & 15.308 & 14.101 & 0 \\
\hline $\mathbf{2 0 1 7}$ & 11.985 & 735 & 0 \\
\hline
\end{tabular}


on the public list, Central Depository of Securities, a. s. (Kotásek, Pihera, Pokorná et al., 2014). Written form is also necessary if during the donation itself the security will not be given away.

The difference in legal regulations is also seen in the possibility of donating securities in the case of death. This institute was introduced by the new Czech Civil Code from 2014. However, the provision of the law is dependent on the condition that the donated will live longer than donor. In such a case, such a procedure is considered to be a will.

Both legal orders in certain cases restrict the owner of the security in dealing with it. In the case of a person whose legal capacity was limited, such person is entitled under Czech law to donate or receive a gift of only of a small value or a donation that is customary in the circumstances. Unlike the Slovak regulation, the donation of a security to a person operating a medical or social facility, or to its employees and administrators, will also be invalid. However, the prohibition applies only to the donation agreement concluded at the time of the donor's residence in such a facility. The aim of this regulation is to protect the people reliant on the care of third parties.

The new Czech Civil Code as well as the previous legislation in the Civil Code from 1964 allows the donor to demand the return of the donation. It is the legal institute of "giving away the donation". But it is possible to appeal for two reasons - for the urgency and for the ingratitude. The revocation of the donation of ingratitude is essentially the same as the Slovak possibility of revocation the gift for contradiction with good morals.

Revoking a doantion for an emergency is a newly established institute. In a situation where a donor, after donation of a security, falls into such an emergency that he or she does not have the means or the necessary nutrition or nutrition of the person he is obliged to take care of and nourish, the donor may appeal. They ask the donated person to return the gift or pay the usual prize. However, its amount is limited to the donor by the amount of resources needed to ensure such nutrition. On the other hand, the law of the donor makes it possible to avoid giving back the donation by providing what is the donor's need for the desired nutrition. In practice, it will usually be to provide a certain amount that would be sufficient to provide nutrition. However, the donor must not return the donation if they are in a similar need as a donor. Such a reason for revoking a donation does not belong to a donor who has brought the state of urgency either deliberately or by gross negligence.

The loan agreement as well as the agreement for the donation of a security in the status of separate contractual types were liquidated together with the Securities Act. In drafting the loan agreement in the new Czech Civil Code, the legislator returned to the name of the Austrian Civil Code and the contractual relationship is called the Lending (czech "Zápůjčka"). This also corresponds to the new designation of the parties. Instead of the former designation, the lender uses the term "zapuijčitel") and instead of the term borrower uses the term "vydlužitel". In the case of a security loan, only provisions of Paragraphs 2390 to 2394 of the Civil Code are to be applied

"The securities loan agreement as well as in the conditions of the Slovak Republic represents a bilateral contractual relationship where the lender passes to the debtor an identifiable security to use it at its own discretion and after a certain period of time to return the security of the same kind. Thus, in the case of a loan, the borrower does not return the same borrowed security to the lender, but another security of the same type" (Peráček, 2015). This is why the subject of the loan agreement may be only substitutable securities, such as en block issued shares. If the value of the securities is changed on the market from the time of the provision of the security until the time of its return, it is not possible to take into account this fact under $\$ 2392$, Section 2 of the Civil Code, and this has also been respected by the previous legislation. When dealing with the issue of securities repayment, the new Czech Civil Code is based on the fact that the loan is a free-of-charge contractual type. This means that the borrower returns only how much he has borrowed. However, in the case of a security loan, it is permissible under Czech law for the parties to agree on an interest which is reasonable. However, in the case of a security rent the parties also have the option of agreeing, for example, on a larger scale, instead of interest of the securities.

Similarly to Slovakia, the maturity of securities is generally left on the agreement of the parties. In the absence of this arrangement, the parties are governed by a law whose dictation is completely different. By law, the maturity of the loan depends on termination of the agreement, with a general notice period of six weeks. However, if no interest is agreed, the borrower can repay the loan even without notice. Another difference in regulation was found in $\S 2394$, which regulated the creditor's ability to leave the agreement and demand repayment of the entire debt and interest in the event of default of the debtor. However, it must be repayment of a loan in installments, with the debtor in delay with the payment of more than two payments or one payment for more than three months. This is a provision taken from the repealed Act no. 513/1991 Coll. Commercial Code as amended.

\section{DISCUSSION}

Despite the general lack of commitment to the issue of securities agreements, we are convinced that certain space should also include a professional discussion on the possibility, for example, temporary donation of securities, the agreement of the parties on the grounds for termination of the donation agreement and the obligation of the donor to return the security. In certain cases, however, it is not possible to agree with the views of individual 
authors, even if they are based on the opinion of the Supreme Court. For example, Fekete (2015) in the Commentary on the Civil Code claims that if the donor is convinced that the donation is against good morals, there is no need for him to call on the donor to return the donation, but it is sufficient that the act is contained in action. From our own advocacy practice, we have the knowledge that the absence of such an act allows the court to dismiss the subsequent action for the determination of ownership of the security at the first hearing because of the lack of substantive conditions.

\section{CONCLUSION}

From the content of the contribution we came to the conclusion that, in the case of a security donation agreement, the agreement is not completely specific but a "subtype" of the donation agreement stipulated in the Civil Code. Therefore, we reject the established hypothesis that the securities donation agreement is a separate contractual type in Slovak Commercial Law. The reasons for our finding are the absence of a legal definition of a agreement for the donation of a security and determination of its essential requirements. In addition to determining the mandatory written form of this contract, the legislator is satisfied only by reference to the general rules in the Civil Code, which may in some cases appear to be inadequate. Similarly, a Czech legislator, who abolished the Securities Act, took up the matter and submerged the issue. Unlike the Civil Code from 1964, this is a more sophisticated adjustment that responds to a number of practical problems. Although in certain cases it makes it possible to conclude the agreement for the donation of securities also verbally, in special cases, the owner of the security is properly limited in its handling. This is especially the case of an absolute nullity of the donation agreement in the case of donation securities to employees of the health and social facilities during their stay there.in such a facility.

In the case of a loan of a security, the situation is different. The Slovak legislator devoted more space to it, and therefore we confirm the hypothesis that it is a separate contractual type in Slovak commercial law. In addition to the legal definition, it is likely that the content is also directly defined in the text of the law. Unlike the general regulation of this institute in the Civil Code, it allows the contracting parties to negotiate a reward in money that only confirms our view that it is a separate contractual type. The subsequent reference to the modification of the rights and obligations of the parties to the general regulation is also common in other contractual types. As mentioned above, the Czech legislator abolished the Securities Act. In practice, this means that even in the case of a security loan, only a general regulation similar to that of the annulled Civil Code is applied. In its analysis, the main difference was that, when returning to the historical name, which also corresponds to the designation of the parties. Similarly to Slovakia, the Czech legislator also allows a form of retaliation for a paid loan. We also mention, in our opinion, a new way of terminating a contract by debtor's delay from a credit agreement from the abolished Commercial Code.

In general, it is possible to agree with the authors' statements led by Eliáš et al. (1999) who have expressed the legal opinion that the whole second part of the Securities Act, the statutes of Sections 30 to $53 \mathrm{f}$ which deal with issues of securities agreements constitute a lex specialis in relation to both Codes. As a clear positive point, it is necessary to point out the statute of Paragraph 261 section 3 letter c of the Commercial Code, which includes all types of trading relations and brokering (Paragraph 642) and, furthermore, the reverse agreements relating to securities, which excludes possible reflections on the application of the Civil Code to these commitment relationships. Thus, the legislator succeeded in eliminating the risk of splitting the legal regime of the implementation of selected types of agreements that might otherwise be subject to the statutes of the Civil Code or the Commercial Code and cause confusion.

This fact also has a direct impact on securities donation and securities lending agreement, which fall are included in the category of "Absolute Non-Commercial Obligations" because the Securities Act also refers to the general arrangement of the donation agreement and the loan agreement in the Civil Code. In particular, for the laypersons, the statute of the first sentence of Paragraph 38 section 3 Securities Act may be that not an agreement for a security but only a binding relationship from a securities loan agreement is governed by the general statute of the Commercial Code of Commercial Obligations.

The content of research in Part Two of the Securities Act does not imply that the legislature would exclude the possibility of entering into other agreements relating to the management of securities. In our opinion, however, it is to the detriment of the fact that the legislator did not regulate the relationship of securities transfer agreements with the legal institute of the Settlement Agreement set out in Paragraphs 524 to 530 of the Civil Code when it may come to a mutual collision because a security under a valid right is a creditor's claim against the debtor.

In analysing and evaluating the function of the securities in the conditions of the Slovak Republic, as well as evaluating the current state of the capital market in Slovakia, we can state that the capital market is characterized by long-term stagnation and the failure of its basic functions. The domestic capital 
market virtually fails to provide effective redistribution of free financial resources, which legitimately raises questions about its meaningfulness. Efforts to make it more effective and provide support are not self-serving, delaying current capital market problems could endanger the long-term stability of the financial sector. In February 2015, the European Commission opened a debate on removing barriers to free movement of capital and created a room for addressing the question of whether there is potential for reviving the domestic capital market and whether it's more efficient functioning can be an added value for the Slovak economy. This view is also based on statistical data obtained from the Central Securities Depository in Bratislava. It follows that, in particular, Securities lending contract as a potential economic instrument for temporary capital formation is used only minimally and falls into forgotten. Similarly, there is also a contract for the donation of securities, the number of registrations of which is below $7 \%$ compared to the purchase agreement, and it is possible to believe that the number of registrations will continue to decline. Such a loss is caused mainly by the distrust of the population in the capital market as well as by the impossibility of transferring into the so-called "Worthless" securities.

\section{REFERENCES}

BAUMACH, A. and HEFERMEHL, W. 1997. Exchange Act and Check Law [in German: Wechselgesetz und Scheckgesetz]. $1^{\text {st }}$ Edition. München: C. H. Beck.

BROX, H. 1983. Business law and Securities Law [in German: Handelsrecht und Wertpapierrecht. $1^{\text {st }}$ Edition. Beck: München.

BULLOW, P. 1991. Exchange Law, Check Law, General Terms and Conditions [in German Wechselgesetz, Scheckgesetz, Algemeine geschäftsbedingungen]. $1^{\text {st }}$ Edition. Heidelberg: C. F. Miller.

ČESKOSLOVENSKÁ SOCIALISTICKÁ REPUBLIKA. 1964. Zákon č. 40 zo dňa 26. 02. 1964 Občiansky zákonník. In: Zbierka zákonov ČSSR. 19: 201-248. Available at: https://www.slov-lex.sk/pravne-predpisy/ SK/ZZ/1964/40/20181001

ČESKÁ A SLOVENSKÁ FEDERATÍVNA REPUBLIKA. 1991. Zákon č. 513 zo dňa 5. 11. 1991 Obchodný zákonník. In: Zbierka zákonov ČSFR. 98: 2474-2565. Available at: https://www.slov-lex.sk/pravne-predpisy/ SK/ZZ/1991/513/20180901

ČESKÁ REPUBLIKA. 1992. Zákon č. 591 ze dne 20. listopadu 1992 o cenných papírech. In: Zbierka zákonov ČSFR. Čiastka 119/1992. Avalaible at: https://www.slov-lex.sk/pravne-predpisy/SK/ ZZ/1992/591/19930101

ČESKÁ REPUBLIKA. 2012. Zákon č. 89 ze dne 3. února 2012 občanský zákonník. In: Sbírka zákonu České republiky. Částka 33/2012. Avalaible at: https://www.zakonyprolidi.cz/cs/2012-89

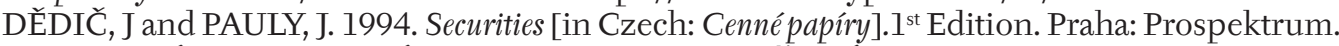

DULAKOVÁ JAKUBEKOVÁ, D., DULAK, A. and JURČOVÁ, M. 2013. Property Transfer, Purchase and Contract Agreements, Consumer Purchase Contract, Gift Agreement; comment [in Slovak: Zmluvy o prevode vlastníctva, kúpna a zámenná zmluva, spotrebitel'ská kúpna zmluva, darovacia zmluva; komentár]. $2^{\text {nd }}$ Edition. Praha: C. H. BECK.

ELIÁŠ, K., BEJČEK, J., MAREK, K. et al. 1999. Business law course - Trade obligations. Securities [in Czech: Kurs obchodního práva - Obchodnízávazky. Cenné papíry]. $2^{\text {nd }}$ Edition. Praha: C. H. BECK.

FEKETE, I. 2015. Civil Code general comment $3^{\text {rd }}$ Editon Inheritence, Commitment Law - general part ( $\$ 460$ to $\$ 587$ ) [in Slovak: Občiansky zákonník velký komentár 3.zväzok Dedenie, záväzkové právo - všeobecná čast' (\$460 až \& 587)].1 $1^{\text {st }}$ Edition. Žilina: Eurokódex.

FEKETE, I. and FEKETEOVÁ, M. 2006. Death donation [in Slovak: Darovanie pre prípad smrti]. Justičná revue, 58(10): 1446-1454.

FILKORN, V. 1956. Method of science [in Slovak: Metóda vedy]. $1^{\text {st }}$ Edition. Bratislava: Slovenská akadémia vied.

KNAPP, V. and GERLOCH, A. 1983. Scientific methods of knowledge of law [in Czech: Védecké metody poznání práva]..$^{\text {st }}$ Edition. Praha: Ústav státni správy.

KOTÁSEK, J. 2017. Securities and liquidation of securities in the Czech law [in German: Wertpapiere and Wertpapierveräuserung im tschechischen Recht]. In: WELSER, R. Ausgewählte Fragen zu Rechtsnatur der Veräusserung, Anlegerschutz, Prospekthaftung und Verjährung nach dem Recht der CEE-Staaten. $1^{\text {st }}$ Edition. Wien: Manz'sche Verlags- und Universitätsbuchhandlung.

KOTÁSEK, J., PIHERA, V., POKORNÁ, J. et al. 2014. Securities Law. [in Czech: Právo cenných papíru]. ${ }^{\text {st }}$ Edition. Praha: C. H. BECK.

KRÁLIK, J. and JAKUBOVIČ, D. 2004. Financial law [in Slovak: Finančné právo]. $1^{\text {st }}$ Edition. Bratislava: VEDA.

LAZAR, J., DULAK, A., JURČOVÁ, M. et al. 2018. Civil Law Material 2 Commitment Law; intellectual property law [in Slovak: Občianske právo hmotné 2 záväzkové právo; právo duševného vlastníctva]. $2^{\text {nd }}$ Edition. Bratislava: IURIS LIBRI.

LEWIN, N. 1999. Corporate Finance: Public Companies and the City. $1^{\text {st }}$ Edition. Bristol: The College of Law, Jordans. MIKITA, D., 2003. How to do it? [in Slovak: Ako na to?]. Ars notaria, 7(4): 25-27.

PERÁČEK, T., 2015. Securities agreements [in Slovak: Zmluvy o cenných papieroch]. ${ }^{\text {st }}$ Edition. Bratislava: Univerzita Komenského v Bratislave 
REVENDA, Z., MANDEL, M, KODERA, J. et al. 2014. Money Economics and Banking [in Czech: Peněžní ekonomie a bankovnictvi]. $5^{\text {th }}$ edition. Praha: Management Press.

SUPREME COURT OF CZECH SOCIALISTIC REPUBLIC. 1972. 42. Rozhodnutie: Jeden z manželov nemôže svoje spoluvlastnícke právo z bezpodielového spoluvlastníctva previest' na druhého manžela, a to ani darovacou zmluvou. In: Zbierka súdnych rozhodnutí a stanovísk. 6/1972. Praha: Najvyšší súd

SUPREME COURT OF CZECH SOCIALISTIC REPUBLIC. 1992. 26. Rozhodnutie: Ak bola darovaná vec zaslaná obdarovanému poštou ako balíková zásielka, nebolo možné prijatie ponuky daru už pri prevzatí v poštovej zásielke, ale až v tom, či sa obdarovaný rozhodol po rozbalení zásielky dar prijat alebo nie. Bolo tu teda potrebné počítat's určitým časovým odstupom, počas ktorého sa obdarovaný môže zoznámit s tým, čo sa mu daruje. In: Zbierka súdnych rozhodnutí a stanovísk. 3/1992. Praha: Najvyšší súd

SUPREME COURT OF THE SLOVAK REPUBLIC. 1997. 61. Rozhodnutie: Za právne relevantné považuje iba také správanie sa obdarovaného, ktoré sa objektívne prejavilo. Pritom nie je rozhodujúci subjektívny pocit a úsudok darcu. In: Zbierka stanovísk NS a rozhodnutí súdov SR 8/1997. Bratislava: SCSR

SUPREME COURT OF THE SLOVAK REPUBLIC. 1999. 31. Rozhodnutie: Za hrubé porušenie dobrých mravov obdarovanýmnemožno považovat'napr. predaj darovanejveci cudzej osobealebonenavštevovanie darcu pri príležitosti sviatkov a jeho životných jubileí. In: Zbierka stanovísk NS a rozhodnutí súdov SR 3/1999. Bratislava: SCSR

SUPREME COURT OF THE CZECH REPUBLIC. 2001. Judgement no. 22Cdo 162/2001. Rozhodnutie:Za prejav vôle darcu voči obdarovanému sa považuje podanie žaloby, ktorou sa žalobca domáha vrátenia daru a to k okamihu jej doručenia obdarovanému. V takom prípade výzvu na vrátenie daru nahrádza samotná žaloba, ak spIňa predpísané náležitosti hmotného práva. Výzva na vrátenie daru musí byt obsiahnutá v tej časti žaloby, ktorá obsahuje opísanie rozhodujúcich skutočností. Doručením rovnopisu takejto žaloby obdarovanému je potom splnená hmotnoprávna podmienka zániku právneho vztahu z darovacej zmluvy. Brno: Supreme Court of the Czech Republic

SUPREME COURT OF THE SLOVAK REPUBLIC. 2002. Judgement no. 5Cdo 130/2002. Rozhodnutie: Správanie členov rodiny obdarovaného voči darcovi je z hl'adiska aplikácie ustanovenia § 630 Občianskeho zákonníka bezpredmetné. Toto ustanovenie nemožno vykladat rozširujúcim spôsobom tak, že sa ním majú postihnút aj dôsledky správania sa iných osôb ako obdarovaného, hoci aj jemu blízkych. Od obdarovaného by nebolo možné spravodlivo požadovat', aby znášal sankcie za správanie sa iných osôb voči darcovi, za ktoré sám nezodpovedá. Bratislava: Supreme Court of the Slovak Republic

SUPREME COURT OF THE CZECH REPUBLIC. 2002. Judgement no. 33 Obdo 47/2002. Rozhodnutie: Nesplatenie zmluvných úrokov v dohodnutej lehote oprávňuje veritel'a vymáhat' od dlžníka aj úrok z omeškania z týchto úrokov. Brno: Supreme Court of the Czech Republic

SUPREME COURT OF THE CZECH REPUBLIC. 2003. Judgement no. 5Tdo 536/2003. Rozhodnutie: Predmet daru môže od samotného darcu prevziat' aj iná osoba, poverená na tento úkon od obdarovaného. Po prevzatí veci je však povinná ju bezodkladne odovzdat' obdarovanému a ak sa tak nestane, dopustí sa trestného činu sprenevery. Brno: Supreme Court of the Czech Republic.

SUPREME COURT OF THE SLOVAK REPUBLIC. 2006. 20. Rozhodnutie: Zabezpečenie uspokojenia pohl'adávky obdarovaného voči darcovi je neplatným úkonom. In: Zbierka stanovísk NS a rozhodnutí súdov SR 3/2006. Bratislava: SCSR

SUPREME COURT OF THE SLOVAK REPUBLIC. 2006. 20. Rozhodnutie: Darovacia zmluva uzavretá za účelom zabezpečenia uspokojenia pohl'adávky obdarovaného voči darcovi je neplatným právnym úkonom. In: Zbierka stanovísk NS a rozhodnutí súdov SR 3/2006i. Bratislava: SCSR.

THE CENTRAL SECURITIES DEPOSITORY OF THE SLOVAK REPUBLIC (2018). Number of registered contracts in years 2010-2017. Send by e-mail, February 14, 2018.

VOJČÍK, P., KRAJČO, J., LALÍK, M. et al. 2010 Civil Code short comment [in Slovak: Občiansky zákonník stručný komentár]. $3^{\text {rd }}$ Edition. Bratislava: Iura Edition.

VÝBOCH, J., 2009. Donation contract in Slovak civil law [in Slovak: Darovacia zmluva v slovenskom občianskom práve]. Právny obzor, 92(3): 241-261.

\section{Contact information}

Tomáš Peráček: tomas.peracek@fm.uniba.sk

Boris Mucha: boris.mucha@fm.uniba.sk

Patrícia Brestovanská: patricia.brestovanska@fm.uniba.sk

Jana Kajanová: jana.kajanová@fm.uniba.sk 